\title{
エチレンがリョクトウモヤシの高温耐性に及ぼす影響
}

\author{
前澤重禮 $* \cdot$ 渡邊和俊・中野浩平・西津貴久・後藤清和 \\ 岐阜大学大学院応用生物科学研究科 501-1193 岐阜市柳戸
}

\section{Effect of Ethylene on the Heat Tolerance of Mung Been Sprouts}

\author{
Shigenori Maezawa*, Kazutoshi Watanabe, Kohei Nakano, Takahisa Nishizu and Kiyokazu Goto \\ Graduate School of Applied Biological Sciences, Gifu University, Yanagido, Gifu 501-1193
}

\begin{abstract}
To discuss the effect of ethylene pre-treatment on the heat tolerance of fresh agricultural produce, we investigated external and physiological quality changes in ethylene pre-treated leaves of mung bean (Vigna radiata) sprouts after incubation at high temperature. Postharvest ethylene pre-treatment for 3 days at $50 \mathrm{ppm}$ induced a delay and reduction of necrosis generation (external quality decrease) at the surface of the leaf after incubation under a high temperature stress condition at $50^{\circ} \mathrm{C}$ for 120 minutes. Moreover, postharvest ethylene pre-treatment induced suppressed the ion leakage rate in the leaf, which is a physiological quality index showing the permeability of the membrane, under a high temperature stress condition at $50^{\circ} \mathrm{C}$ for 60 minutes. However, the respiration rate and lipid peroxidation extent of the leaf were not influenced by postharvest ethylene pre-treatment. These results showed that ethylene pre-treatment after harvest generate high temperature stress tolerance in the leaf, suggesting that ethylene has the potential to reduce membrane impairment, which is related to high temperature injury.
\end{abstract}

Key Words : electrolyte leakage, heat damage, necrosis, peroxide lipid

キーワード : 壊死，イオン漏出率，過酸化脂質，高温障害

\begin{abstract}
緒言
エチレンはストレス応答に関わる植物ホルモンであり， 老化成熟促進作用があることはよく知られているが，ス卜 レス耐性を高める作用があることも報告されている，例え ば，エチレン前処理によって，耐病性（Stahmann ら，1966）, 抗酸化性（Mehlhorn, 1990）, 高温耐性（Larkindale・Huang, 2004; Larkindale • Knight, 2002), 低温耐性（Lipton・Aharoni, 1979）が向上した例がある。この中で，高温耐性を向上さ せる作用は注目に值する。 なぜなら, 高温は農作物の栽培 から収穫後の流通段階を通して重要なストレス要因となっ て未り, 高温耐性の獲得や向上は栽培中や収穫後の農産物 の損失量の低減や品質管理の点で潜在的価值が高いと考え られるからである. 例えば, 收穫後の青果物を高温殺菌, 殺 虫する際にしばしば生じる高温障害を抑制できることにつ ながる，ところが，エチレンにより收穫後青果物の高温耐 性が向上される例は未だ見いだされていない，そこで，本 研究ではエチレンが収穫後青果物の高温耐性特性に及ぼす 影響を把握するため, エチレン処理した青果物の高温障害
\end{abstract}

2010 年 2 月 16 日 受付. 2010 年 8 月 17 日 受理. 本研究の一部は平成 21 年度園芸学会東海支部大会で発表した.

*Corresponding author. E-mail: maezawa@gifu-u.ac.jp
程度を調べるとともに，その生理的影響を，イオン漏出率， 脂質過酸化レベル打よび呼吸速度を指標として検討した。

細胞内に存在する種々の小器官を構成する膜の構造と機 能は，植物が遭遇している環境によって影響を受ける。そ のため, 膜の構造と機能の安定性は, 種々のストレスの影 響を反映する重要な指標と見なすことができる，高温は膜 タンパク質の構造を変化させることで，また，高温によっ て生じる活性酸素は膜脂質を過酸化することで, 膜の透過 性を増大させる（Wahidら，2007）。本研究では, エチレン による高温耐性の生理的な要因を明らかにするために，膜 の透過性をイオン漏出率として, 膜脂質の過酸化レベルを チオバルビッール酸反応物質（TBARS）として調ベた。 ま た，エチレンは呼吸速度の増大を誘導する植物ホルモンで あるため（Kieber, 2004），エチレン処理したモヤシ葉部の 高温処理後の呼吸速度を $\mathrm{CO}_{2}$ 排出速度として調べた.

エチレンの農業への応用といら視点で，双子葉植物の形 態形成に対するエチレン作用の研究が，食用のリョクトウ モヤシに関して報告されている（森，2002）。 たた，リョク トウモヤシは栽培温度履歴を容易に調整できるため，エチ レン処理してから一定温度環境 $\left(50^{\circ} \mathrm{C}\right)$ に静置した後の植 物生理学的特性を分析する本研究の実験材料として相応し いと考えた. 


\section{材料および方法}

\section{1. 青果物材料}

リョクトウ（Vigna radiata）を播種し， $25^{\circ} \mathrm{C}$ の暗黒下で 水耕栽培し, 草丈が約 $10 \mathrm{~cm}$ に成長した 5 日目に, 上胚軸 の葉部をハサミで切断して実験に供試した.

\section{2. エチレン前処理}

本研究におけるエチレン処理条件を検討するために, ま ず予備実験として種々のエチレン濃度と処理時間を組合せ た条件で外観上の高温ストレス耐性を調べた。すなわち, $0 ， 5 ， 50$ および $500 \mathrm{ppm}$ のエチレン濃度で $2 ， 12 ， 24,48$ および 72 時間暗黒下でエチレン処理した. その結果, 処理 時間 12 時間以下では効果がなかったが, 24 時間では 50 ppm 以上で認められ，48 時間以上の処理時間では， $5 \mathrm{ppm}$ 以上 のすべての濃度条件で観察され, 特に, 72 時間（3 日）で 顕著であった。 そのため本研究でのエチレン処理濃度は, 濃度調整が容易な $50 \mathrm{ppm}$ とし, 処理時間は 3 日間とした。 処理温度は, エチレンとストレスとの関係を論じた先行研 究 (Larkindale・Huang, 2004; Larkindale・Knight, 2002; Lipton・ Aharoni, 1979; Mehlhorn, 1990; Stahmann ら, 1966) に準じて 常温 $20^{\circ} \mathrm{C}$ とた.

具体的なエチレン処理としては, まずモヤシ葉部 90 枚を 蒸留水で湿らせたろ紙上に置き, 円筒チャンバー（内径 $16 \mathrm{~cm} \times$ 高さ $24 \mathrm{~cm}$ ) に入れた後, 容器内エチレン濃度が 50 $( \pm 5) \mathrm{ppm}$ となるよらにエチレンを注入し， $20^{\circ} \mathrm{C} て ゙ 3$ 日間 静置した.

\section{3. 高温ストレス処理}

エチレン処理したモヤシ葉部に高温ストレスを与えるた めの温度条件を検討するため, 予備実験として45 および $50^{\circ} \mathrm{C}$ で 1,2 および 3 時間の高温ストレスを暗黒下で与え

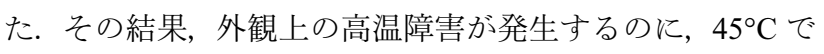
は 3 時間, $50^{\circ} \mathrm{C}$ では 2 時間を要した. 本研究では, 処理時 間の短い $50^{\circ} \mathrm{C}, 2$ 時間を高温ストレス処理条件とした.

高温ストレス処理はチャンバーから取り出したモヤシ葉 部をシャーレに入れて蓋をして, $50^{\circ} \mathrm{C}$ のインキュベータに 2 時間静置した.

\section{4. 高温ストレス処理による外観変化の評価}

高温ストレスによる外観変化は, 壊死面積比によって評 価した. 高温ストレス処理が終了してから 30 分間放冷後の 葉を白紙の上に置いて写真撮影し, その画像を画像解析y フト Image Jを用いて解析した. すなわち, 画像を二值化し て一定の閾值で, 葉面積と黒色濃度の濃い部分（壊死斑点） の面積を測定し, 葉面積に対する壊死斑点の面積の割合を 壊死面積比とした $(\mathrm{n}=10)$. 葉の陰の算入が若干観察され たが，誤差範囲内であった. エチレン処理区と無処理区に 関する有意差検定は， $\mathrm{t}$ 検定により 5\%水準で実施した.

\section{5. 高温ストレスの生理的影響の評価}

$10 \mathrm{~mL}$ の蒸留水に葉を 5 枚 $(0.15 \pm 0.02 \mathrm{~g})$ 入れて 60 分 間振とらし, その後煮沸した. イオン漏出率は, 煮沸後の
電気伝導度に対する振とら 60 分間後の電気伝導度の比とし て求めた. イオン漏出率は高温ストレス処理時間 $0,20,60$ および 120 分間について調べた.

呼吸速度は, 葉 10 枚 $(0.31 \mathrm{~g})$ を 15 分間密封し, ガス クロマトグラフィーを用いて $\mathrm{CO}_{2}$ 濃度の増加速度として求 めた.

脂質過酸化レベルは，Maoら（2007）の方法に準じて, TBARS によって決定した. すなわち, 凍結乾燥した葉 3 枚 $(0.09 \mathrm{~g})$ を $0.1 \mathrm{M}$ リン酸緩衝液（pH 7.0） $3 \mathrm{~mL}$ 中で磨砕し, 遠心分離 $(10,000 \mathrm{~g}, 20$ 分）した上澄夕液 $1.5 \mathrm{~mL}$ に, $0.5 \%$ チオバルビッール酸含有の $10 \%$ トリロロ酢酸溶液 $3 \mathrm{~mL}$ を加え, 15 分間沸騰後に 532 および $600 \mathrm{~nm}$ における吸光 度を測定して求めた。

それぞれの実験に打いて，エチレン処理区と無処理区の 有意差検定は, 3反復して得られた実験データをチューキー 法により 5\%水準で実施した.

\section{結果}

\section{1. エチレンが高温ストレス処理前後のモヤシ葉部の外観 品質に及ぼす影響}

エチレンが高温ストレス処理前後のモヤシ葉部の外観に 及ぼす影響を，第 1 図に示した。高温ストレス処理前にお いて，エチレン無処理区とエチレン処理区の葉色はともに
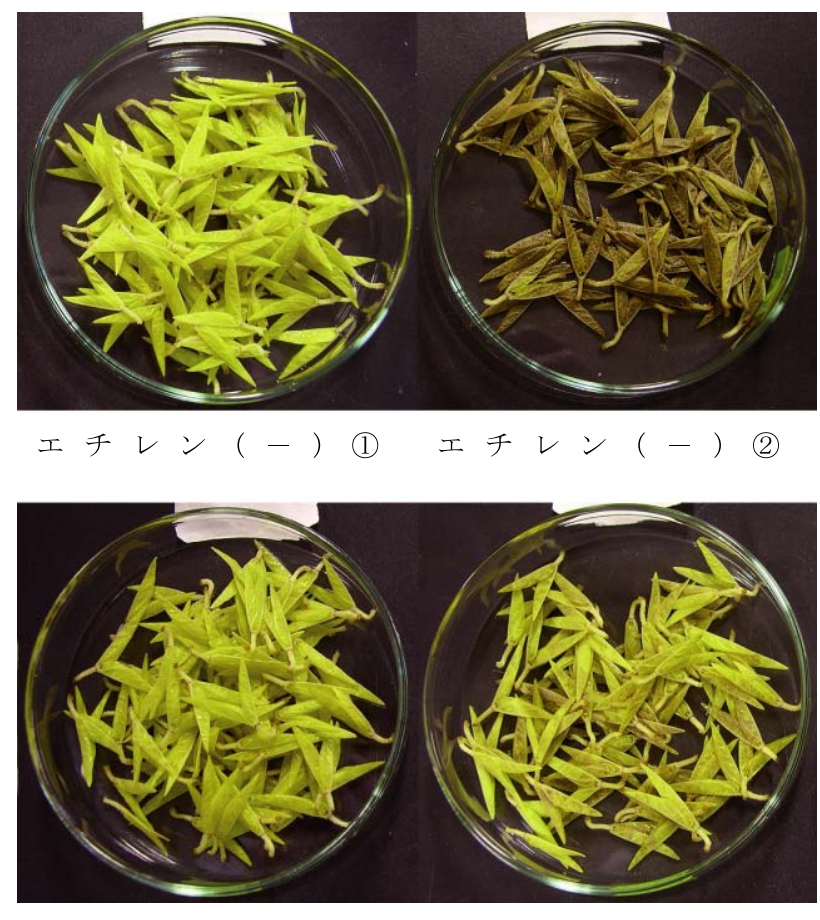

エチレン (+) (1) エチレン ( + ) (2)

第 1 図エチレンがモヤシ葉部の高温ストレス処理前後の外 観に及ぼす影響

上段はエチレン (-)，下段はエチレン $(+)$

(1)は高温ストレス前 (0分), (2)は高温ストレス後(120分) モヤシ葉部に $50 \mathrm{ppm}, 3$ 日のエチレン前処理を施した後 に, 120 分間, $50^{\circ} \mathrm{C}$ の高温ストレスに曝露した 
第 1 表 エチレンが高温ストレス処理後のリヨクトウモヤシ 葉部の壊死面積比に及ぼす影響

\begin{tabular}{ccc}
\hline \hline & エチレン (-) & エチレン (+) \\
\hline 壊死面積比 $(\%)$ & $75.0 \pm 13.2 \mathrm{~b}$ & $23.5 \pm 9.4 \mathrm{a}$ \\
\hline
\end{tabular}

平均值 \pm 標準偏差, $\mathrm{n}=10$

異なるアルファベット間には 5\%水準で有意差あり（T 検定 による）

モヤシ葉部に $50 \mathrm{ppm}, 3$ 日のエチレン前処理を施した後に, 120 分間, $50^{\circ} \mathrm{C}$ の高温ストレスに曝露した

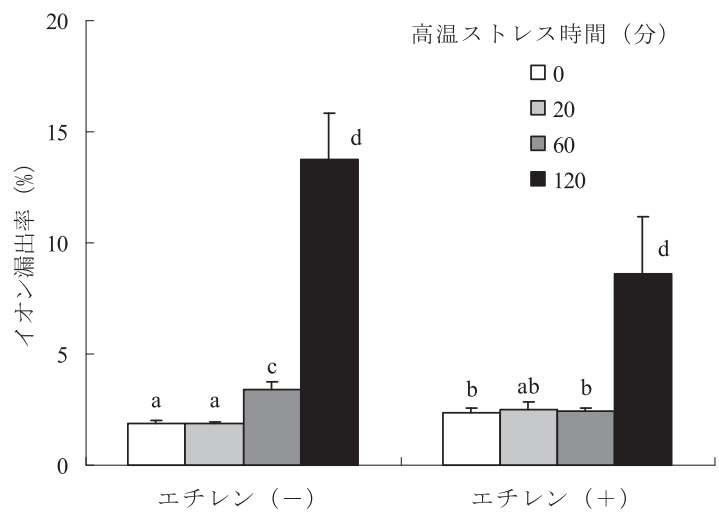

第 2 図高温処理時間がエチレン処理後または未処理のモヤ シ葉部のイオン漏出率に及ぼす影響

誤差線は標準偏差, $\mathrm{n}=3$

異なるアルファベット間には $5 \%$ 水準で有意差あり (チューキー法による)

モヤシ葉部に $50 \mathrm{ppm}, 3$ 日のエチレン前処理を施した後 に, 20, 60 そして 120 分間, $50^{\circ} \mathrm{C}$ の高温ストレスに曝 露した

収穫時と同じ淡黄色であり，変化はなかった。ところが， 高温ストレス 90 分後に外観を目視により確認したところ, エチレン無処理区では褐色の壊死斑点が生じていたが，エ チレン処理区では生じていなかった。 さらに，高温ストレ ス 120 分区において, 壊死斑点の程度は, エチレン無処理 区では著しかったが，エチレン処理区では軽微であった。 高温処理後もモヤシ葉部は十分犰ており, 乾燥被害は見 られなかった. シャーレ内の試料数が少ない場合，葉が乾 燥してしまうことがあるが，今回のように十分多くの葉 （90 枚）を用いた場合は乾燥することはなかった.

次に, 高温ストレス後の壊死面積比にエチレンが及ぼす 影響を，第 1 表に示した. 壊死面積比はエチレン無処理区 に対し，エチレン処理区の方が低かった。これらのことは， 貯蔵中にエチレンがモヤシの外観品質へ悪影響を及ぼさな いこと，また，高温ストレスによるモヤシの外観品質の低 下をエチレンが防ぐことを示している.

\section{2. エチレンが高温ストレス処理前後のモヤシ葉部の生理 的変化に及ぼす影響}

エチレンが高温ストレス前後のモヤシ葉部のイオン漏出 率に及ぼす影響を, 第 2 図に示した. 高温ストレス 0 分（高 温処理をしない区）に拈いて，エチレン無処理区よりもエ

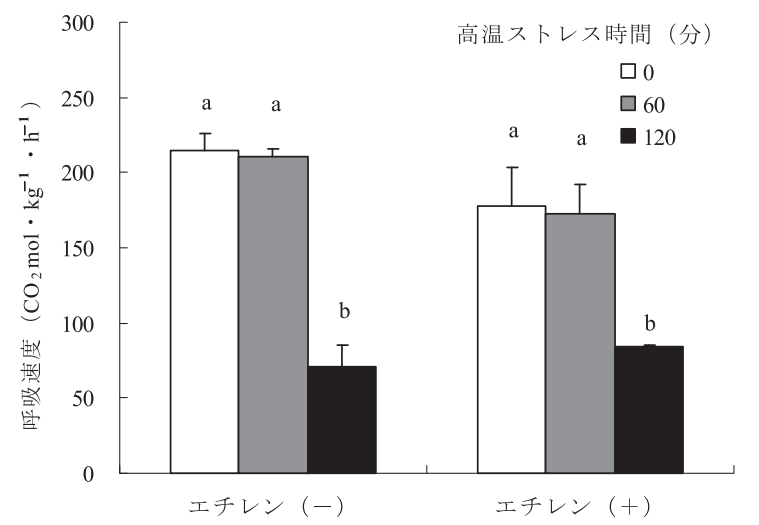

第 3 図エチレン前処理がモヤシ葉部の高温処理直後の呼吸 速度に及ぼす影響

誤差線は標準偏差, $\mathrm{n}=3$

異なるアルファベット間には $5 \%$ 水準で有意差あり (チューキー法による)

モヤシ葉部に $50 \mathrm{ppm}, 3$ 日のエチレン前処理を施した後 に, 60 打よび 120 分, $50^{\circ} \mathrm{C}$ の高温ストレスに曝露した

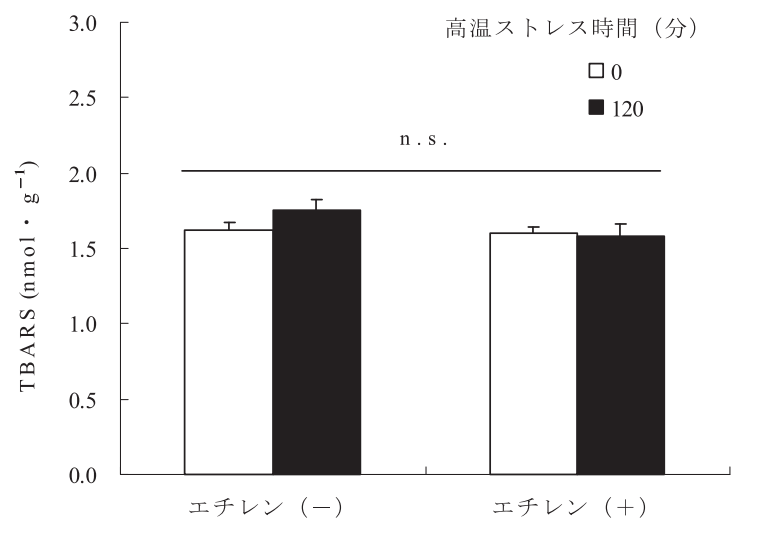

第 4 図エチレン前処理がモヤシ葉部の高温ストレス処理前 後の脂質過酸化レベルに及ぼす影響

誤差線は標準偏差, $\mathrm{n}=3$

実験区間にチューキー法により 5\%水準で有意差なし (n.s. = non-significant)

モヤシ葉部に $50 \mathrm{ppm}, 3$ 日のエチレン前処理を施した後 に， 120 分間， $50^{\circ} \mathrm{C}$ の高温ストレスに曝露した

チレン処理区の方がイオン漏出率は高かった。 しかし，高 温ストレス処理 60 分後の時点では, エチレン無処理区より もエチレン処理区でイオン漏出率が抑制された. 第 3 図に, エチレンがモヤシ葉部の高温処理中の呼吸速度に及ぼす影 響を示した。両区とも高温処理 120 分後に呼吸が阻害され たが，阻害の程度に差はなかった。第 4 図に，エチレンが 高温処理前後の脂質過酸化レベルに及ぼす影響を示した. 両区とも，脂質過酸化レベルは高温処理によって増加しな かった。

\section{考察}

植物に打けるエチレン生成は，1-アミノシクロプロパン -1-カルボン酸（ACC）に ACC 合成酵素が作用して進行す 
る.エチレン関連物質が高温耐性に及ぼす影響を調べた先 行研究 (Larkindale・Knight, 2002) では, シロイヌナズナ (Arabidopsis thaliana) の幼芽を $20^{\circ} \mathrm{C}$ で栽培し， $40^{\circ} \mathrm{C}$ の高 温に 1 時間曝露すると, 著しい生存率の低下と TBARS の 増加が見られたが，エチレン前駆物質の ACCで前処理す ると, 生存率の低下や TBARS の増大は軽微に抑兄られ, さ らに, シロイヌナズナのエチレン受容体変異株（etr-1）に $37^{\circ} \mathrm{C}$ の高温ストレスを与えたところ, 野生株よりも生存率 の低下と TBARS の増加が激しくなることが報告されてい る.これらの結果を踏まえて, Larkindale・Knight (2002) は，エチレン関連物質が脂質の過酸化を抑制することで高 温障害の結果である細胞死滅を防ぎ，それはエチレン受容 体を介して起こる反応であることを示唆した. また, クリー ピングベントグラス（Agrostis stolonifera L.）に扔いても, $35^{\circ} \mathrm{C}$ の高温ストレスによって, クリーピングベントグラス の品質の低下, 光合成能低下抽よび TBARS 増大が生じる が，エチレン前駆物質の ACC で前処理するとそれらが軽 微になることが報告されている (Larkindale・Huang, 2004). さらに, 同報では, 高温ストレス中のアスコルビン酸ペル オキシダーゼ（APX），ペルオキシダーゼ，カタラーゼ拈よ びスーパーオキシドジスムターゼといった抗酸化酵素の活 性は, ACC 前処理区の方が無処理区よりも高くなることも 報告している. また, $\mathrm{ACC}$ 前処理によって, 高温ストレス 中に起こるアミノ酸漏出の増大が抑制される（Larkindale・ Huang, 2005). このように, 先行研究においては, エチレン 前駆物質の ACC に着目して植物の高温耐性機構が議論さ れてきた。そして，Larkindaleら（2005）はエチレンによ る高温耐性のメカニズムとして, エチレンにより抗酸化物 質が生じ, それが酸化障害を防ぐといら説を提案して抢り， Kotak ら（2007）も同様のことを報告している. エチレン が抗酸化酵素である APX を誘導して酸化障害を防ぐ例は, リョクトウ緑化幼芽に扮いても報告されている (Mehlhorn, 1990). 本研究に扮いても, モヤシ葉部において, 高温障害 による外観品質の低下とイオン漏出率の増加は，エチレン 前処理によって抑制され, 先行研究と類似する結果を示し た(第 1,2 図).ところが, 膜の過酸化レベルを示す TBARS は高温ストレスによって増加せず, 先行研究と異なった(第 4 図). 高温による酸化障害は光依存的に起こる例が報告さ れているため (Larkindare・Knight, 2002), 本研究で, 脂質 過酸化が見られなかった原因として, 無光条件で高温処理 をしたことと，拈よび，モヤシには葉緑体が未発達である ことにより, 葉緑体のエネルギー伝達機構での活性酸素の 生成が少なかったことが考兄られる。 また, 高温による脂 質過酸化レベルの増大が見られなかったことから, 高温障 害の生理機構として, 膜の過酸化を介さない経路で細胞に 障害を与える可能性があると考兄られた. エチレンにより， 高温ストレスによる著しいイオン漏出率増大は抑制された が，エチレン処理中に軽微なイオン漏出率の増大が見られ た (第 2 図). 膜機能の䚻失と膜流動性の過度の増大は相関
しており（Bressan ら，2004）, 膜流動性の過度の増大は高 温障害の原因になる，その一方で，膜流動性の増大は，高 温耐性を誘導するシグナル伝達の上流に位置すると考えら れている（Sung ら，2003; Wahid ら，2007). エチレン前処 理中に軽微なイオン漏出率の増大が見られ，その後の高温 耐性が向上したことは，この考皃を支持している.

高温による壊死程度に差があるにも関わらず，呼吸阻害 の程度にはエチレン処理効果は見られなかった（第 3 図）。 ただ，高温ストレス処理時間が 60 分間以上になると，呼吸 反応が大きく抑制され，エチレンはこの抑制には影響を及 ぼさないことが示された，このことより，エチレン処理は 外観変化に影響をもたらすものの，ミトコンドリア内のエ ネルギー代謝にはほとんど影響を及ぼさないことが示唆さ れた。

興味深いことに，エチレンは高温障害だけでなく低温障 害も抑制することがある。例光ば，エチレンはマスクメロ ンの低温による外観の障害を抑制する（Lipton・Aharoni, 1979).このことは, エチレンによる低温耐性と高温耐性の 関係について，共通するメカニズムがあることを示唆して いる.

本研究で, エチレン処理によってモヤシの高温耐性が誘 導される現象を見いだした。これは，収穫後青果物におい ては初めての知見であり, 他の收穫後青果物へ適用できる 可能性を示唆している. 例えば, バナナ, アボガド, マン ゴーなどの輸出用青果物は殺虫, 殺菌のため収穫後に高温 処理されることが多いが (Couey・Hayes, 1986; Fallikら， 2001), 過度に行うと内部褐変や追熟不良などの高温障害を 生じる（Wills ら，1998）ことが問題となっている. これら の果実はリョクトウモヤシとは植物学的に器官が異なり, 生育ステージも異なるため, リョクトウモヤシの知見が直 ちに果実の高温障害の問題解決に反映できるわけではな い. しかし，栽培中の温度履歷を完全に制御した本実験成 果は, 他の青果物への応用を検討する今後の実験設計に役 立つであろう。

\section{摘 要}

収穫後青果物のエチレン処理が貯蔵中の高温耐性に及ぼ す影響を議論するため, 制御された環境で栽培されたりョク トウモヤシ葉部をエチレン処理した後に高温処理し,外観と 生理的特性の変化を調べた．エチレン濃度 $50 \mathrm{ppm}$ で 3 日間 前処理すると, 高温ストレス環境 $\left(50^{\circ} \mathrm{C}, 120\right.$ 分）曝露後の 葉部に抢ける壊死発生 (外観品質の低下) の遅延と軽減が誘 導された. さらに, エチレン処理することによって, $50^{\circ} \mathrm{C}$, 60 分の高温ストレス環境下に拈けるイオン漏出割合（イオ ンの膜透過性）の抑制が観察された. 一方，呼吸速度や膜脂 質の過酸化程度には, エチレン前処理の影響は見いだされな かった. これらの結果は, リョクトウモヤシに対する収穫後 のエチレン処理によって, 高温ストレス耐性が誘起されるこ とを示しており，エチレンには高温障害に関連する膜損傷を 
軽減する作用があることが示唆された，以上の知見は，收穫 後青果物の高温障害の抑制に対するエチレンの効用を検討 することの重要性を示唆している.

\section{引用文献}

Bressan, R. A., D. E. Fosket and P. M. Hasegawa. 2004.ストレ 又生理学. p. 601-634. L. Taiz and E. Zeiger編. 植物生 理学 (第3版). 西谷和彦, 島崎研一郎監訳. 培風館. 東京.

Couey, M. H. and C. F. Hayes. 1986. Quarantine procedure for Hawaiian papaya using fruit selection and a two-stage hotwater immersion. J. Economic Entomology. 79: 1307-1314.

Fallik, E., S. T. Alkalai, X. Feng and S. Lurie. 2001. Ripening characterization and decay development of stored apples after a short prestorage hot water rinsing and brushing. Innovative Food Sci. Emerging Technol. 2: 127-132.

Kieber, J. 2004. エチレン． p. 525-546. L. Taiz and E. Zeiger 編. 植物生理学 (第 3 版). 西谷和彦, 島崎研一郎監 訳. 培風館. 東京.

Kotak, S., J. Larkindare, U. Lee, P. von K. Doring, E. Vierling and K. D. Scharf. 2007. Complexity of the heat stress response in plants. Current Opinion Plant Biol. 10: 310316.

Larkindale, J., J. D. Hall, M. R. Knight and E. Vierling. 2005. Heat stress phenotypes of Arabidopsis mutant implicate multiple signaling pathways in the acquisition of thermotolerance. Plant Physiol. 138: 882-897.

Larkindale, J. and B. Huang. 2004. Thermotolerance and antioxidant systems in Agrostis stolonifera: Involvement of salicylic acid, abscisic acid, calcium, hydrogen peroxide, and ethylene. J. Plant Physiol. 161: 405-413.

Larkindale, J. and B. Huang. 2005. Effect of abscisic acid, salicylic acid, ethylene and hydrogen peroxide in thermotolerance and recovery for creeping bentgrass. Plant Growth
Regul. 47: 17-28.

Larkindele, J. and M. R. Knight. 2002. Protection against heat stress-induced oxidative damage in Arabidopsis involves calcium, abscisic acid, ethylene and salicylic acid. Plant Physiol. 128: 682-695.

Lipton, W. J. and Y. Aharoni. 1979. Chilling injury and ripening of 'Honey dew' muskmelons stored at $2.5^{\circ}$ or $5^{\circ} \mathrm{C}$ after ethylene treatment at $20^{\circ} \mathrm{C}$. J. Amer. Soc. Hort. Sci. 104: 327-330.

Mao, L., H. Pang, G. Wang and C. Zhu. 2007. Phospholipase D and lipoxygenase activity of cucumber fruit in response to chilling stress. Postharvest Biol. Tech. 44: 42-47.

Mehlhorn, H. 1990. Ethylene-promoted ascorbate peroxidase activity protects plants against hydrogen peroxide, ozone and paraquat. Plant Cell Environ. 13: 971-976.

森 仁志. 2002. エチレン. p. 91-113. 小柴恭一・神谷勇 治編. 新しい植物ホルモンの科学. 講談社サイエンティ フィク. 東京.

Stahmann, M. A., B. G. Clare and W. Woodbury. 1966. Increased disease resistance and enzyme activity induced by ethylene and ethylene production by black rot infected sweet potato tissue. Plant Physiol. 41: 1505-1512.

Sung, D. Y., F. Kaplan, K. J. Lee and C. L. Guy. 2003. Acquired tolerance to temperature extremes. Trends Plant Sci. 8: 179187.

Wahid, A., S. Gelani, M. Ashraf and M. R. Foolad. 2007. Heat tolerance in plants: An overview. Environ. Exp. Bot. 61: 199-223.

Wills, R., B. McGlasson, D. Graham and D. Joyce. 1998. Pathology, p. 144-158. In: R. Wills, B. McGlasson, D. Graham and D. Joyce (eds.). Postharvest (4th ed.). Hyde Park Press, Adelaide, South Australia. 